\title{
Using comparative analysis to teach about the nature of nonstationarity in future flood predictions
}

\author{
S. B. Shaw ${ }^{1}$ and M. T. Walter ${ }^{2}$ \\ ${ }^{1}$ Department of Environmental Resources Engineering, SUNY College of Environmental Science and Forestry, Syracuse, \\ NY 13210, USA \\ ${ }^{2}$ Department of Biological and Environmental Engineering, Cornell University, Ithaca, NY 14853, USA
}

Correspondence to: S. B. Shaw (sbshaw@esf.edu)

Received: 30 November 2011 - Published in Hydrol. Earth Syst. Sci. Discuss.: 21 December 2011

Revised: 11 April 2012 - Accepted: 12 April 2012 - Published: 3 May 2012

\begin{abstract}
Comparative analysis has been a little used approach to the teaching of hydrology. Instead, hydrology is often taught by introducing fundamental principles with the assumption that they are sufficiently universal to apply across most any hydrologic system. In this paper, we illustrate the value of using comparative analysis to enhance students' insights into the degree and predictability of future nonstationarity in flood frequency analysis. Traditionally, flood frequency analysis is taught from a statistical perspective that can offer limited means of understanding the nature of non-stationarity. By visually comparing graphics of mean daily flows and annual peak discharges (plotted against Julian day) for watersheds in a variety of locales, distinct differences in the timing and nature of flooding in different regions of the US becomes readily apparent. Such differences highlight the dominant hydroclimatological drivers of different watersheds. When linked with information on the predictability of hydroclimatic drivers (hurricanes, atmospheric rivers, snowpack melt, convective events) in a changing climate, such comparative analysis provides students with an improved physical understanding of flood processes and a stronger foundation on which to make judgments about how to modify statistical techniques for making predictions in a changing climate. We envision that such comparative analysis could be incorporated into a number of other traditional hydrologic topics.
\end{abstract}

\section{Introduction}

Comparative analysis has not been a broadly used tool in hydrology, especially with respect to elucidating processes. This can possibly be attributed to hydrology's traditional orientation to the physical sciences. This orientation has fostered a mentality of seeking universalities by reducing hydrologic systems to sufficiently small components. A classic example is the development of the Hortonian runoff concept (e.g. Horton, 1933), which corresponded well with smallscale soil infiltration research, which, in turn, was used to test analytical solutions of the perceived mechanisms. Such infiltration models were then implemented in watershed-scale models such as SWAT (Gassman et al., 2007) with the presumption the small-scale processes would aggregate to replicate watershed-scale processes. Thus, a comparative analysis of hydrologic phenomenon at the scale of interest (i.e. watersheds) has often been considered unnecessary given a presumed ability to directly simulate the differing physical mechanisms that underlay the watershed scale phenomenon.

In contrast, comparative analysis has been a relatively standard tool in social sciences, as recognized in the names of social science publications like Comparative Social Research, Comparative Political Studies, and Comparative Studies of Social History. With little illusion that complex social, political, and economic dynamics can be modeled using a reductionist approach, social scientists have sought to develop analytical approaches to directly compare real-world social phenomena. This acceptance of comparative analysis in social science is not surprising given that social scientists such as geographers have inherently sought to draw out unique aspects of different locales (e.g. the longest river in 
Europe; the primary export of central America, etc.), instead of seeking to establish universalities across locales.

Applying the term "comparative hydrology" to watershedscale analyses is relatively rare - an ISI Web of Science ${ }^{\text {sM }}$ search using the terms "comparative hydrology" and "watershed" (28 September 2011) returned four publications (Andrade, 1999; Porto et al., 2004; de Araujo et al., 2009; Thompson et al., 2011). Besides the publications turned up by the ISI search, there have been several notable recent studies squarely in the spirit of comparative analysis that have assessed flood processes (Merz and Blöschl, 2009; Villarini and Smith, 2010; Villarini et al., 2011b) and hydrologic response to climate-vegetation interactions (Sivapalan al., 2011; Voepel et al., 2011) across regions. This is not to say that the idea of comparative analysisis is particularly new. Paired watershed studies have been carried out since the early 20th century (Andreassian, 2004), although these studies have often focused on single features such as forested and non-forested land use. While slightly outside the realm of hydrology, comparative analysis has long been present in watershed ecology and biogeochemical studies (e.g. Vitousek and Reiners, 1975; Mayer et al., 2002; Peters et al., 2006; Tripler et al., 2006). Despite its occasional past use and its seeming new emergence, comparative analysis has not been a dominant research approach in the hydrologic sciences.

Because comparative analysis has traditionally had a limited role in hydrologic research, it is no surprise that it has had limited use in the teaching of hydrology. A review of several commonly used textbooks (Dunne and Leopold, 1978; Black, 1991; Hornberger, 1998; Dingman, 2002; Viessman and Lewis, 2003; Ward and Trimble, 2004; Brutsaert, 2005) revealed that it is common to include tables and/or maps of global or national (US) variations in precipitation, snow, evapotranspiration, and runoff rates, but there are very few examples of comparative analyses linking these types of data to watershed-scale processes. Notable exceptions included analyses comparing: Hortonian and Saturations Excess storm runoff processes using data from Northeastern and Southwestern US watersheds (Dunne and Leopold, 1978, p. 337), the interactions between transpiration and water yield using data from several watersheds (Dunne and Leopold, 1978, p. 153; Dingman, 2002, p. 308), and the interactions between precipitation and potential evapotranspiration on the seasonal soil water budget using data from 17 locations around the US (Ward and Trimble, 2004, p. 116).

\subsection{A topic seeking comparative analysis: flood frequency in a changing climate}

One area in which comparative hydrology might be particularly useful is in the teaching of flood frequency analysis. The roots of flood frequency analysis are in statistics. In the early 20th century, when there was first a strong interest in predicting the occurrence of flooding, hydrologists often had only a decade or two of stream discharge data available. Furthermore, meteorological observations were similarly limited in duration and much less rich in information relative to the extensive meteorological data currently available from satellites, ground-based radars, and weather stations. With limited ability to connect hydrologic phenomenon with meteorological drivers and a short hydrologic data set, it was a logical step for hydrologists to adapt the use of probability functions to infer the magnitude of floods with return periods far larger than the duration of the hydrologic record. There have been notable efforts to infuse a more process-based understanding of flooding into the traditional statistical approach. Starting with Eagleson's (1972) quantification of linkages between storm event characteristics (size and intensity) and catchment response characteristics, there have been a number of papers that have explored the physical basis of flood frequency distributions (e.g. Robinson and Sivaplan, 1997; Blöschl and Sivapalan, 1997; Fiorentino and Iacobellis, 2001). However, these studies most often focus on issues of scale and innate watershed features. More rarely has there been a systematic consideration of flooding that has focused on categorizing the various climatological phenomenon that are the basis for variations in storm event characteristics from region to region. To date, the primary example of such an investigation is the work by Hirschboeck to establish a hydroclimatological framework for reconceptualizing flood frequency distributions as being a combination of different storm types associated with different meteorological features and circulation patterns (Hirschboeck, 1988 and Hirschboeck et al., 2000). Despite this work, a statistics based approach to flood frequency analysis has persisted to the present, especially in engineering hydrology.

Because probability distributions are applied to data assumed to be identically distributed in the statistical sense, an often stated requirement of most statistical approaches to flood frequency analysis is stationarity, i.e. the flood record of the past will be representative of the flood record of the future. With a changing climate, the suitability of the stationarity assumption has been called into question (Milly et al., 2008). However, mathematically it is not that difficult to allow for non-stationarity in the statistical model's structure. Several papers (Katz et al., 2002; El Aldouni et al., 2007; Leclerk et al., 2007; Stedinger and Griffis, 2011) have presented the idea of using the same probability distributions as when assuming stationarity but in making the parameters dependent on external factors to allow for non-stationarities. For instance, to estimate discharge in basins in the northeastern US and Canada, Leclerk et al. (2007) made the location parameter of the GEV distribution a time-dependent function of a multivariate regression model. Likewise, for the log Pearson 3 distribution, Stedinger and Griffis (2011) considered the option of shifting the mean if the magnitude of a flood were expected to change in time and considered the option of shifting the mean and standard deviation if the underlying flood causative process were to change. As another alternative, Sivapalan and Samuel (2009) applied a 
risk model that allowed for variation in time of the probability density function (pdf) of annual maximum discharge. It was anticipated that the pdf would vary depending on the state of a decadal-scale climate oscillation such as ENSO and that the cumulative risk would change as the presumed frequency of certain states changed (as they might in a changing climate). Furthermore, there have long been mixture models (Rossi et al., 1984) in which an annual maximum discharge was presumed to be the result of two or more differently distributed populations where the dominance of each population was scaled by a weighting factor. This weighting factor could be changed in a changing climate if the dominance of a process were presumed to change.

Despite the relative ease with which statistical models can be mathematically reformulated to allow for non-stationarity, such changes need to be coupled with fundamental insights into underlying flood causative processes. It may be straightforward to note that the scale parameter could be changed but it can be much harder know when and by how much to change it. Along these lines, Merz and Blöschl (2008) have recently suggested the value of emphasizing flood frequency hydrology (in contrast to flood frequency statistics) to more systematically elucidate factors important to flood estimation often overlooked when only focused on statistical estimation. Their examples primarily emphasize the need to evaluate site specific information such as peculiarities of gage location, localized variations in geology, or evidence of historically large floods not in the formal gage record. However, the intent is clear; hydrologists need to more directly analyze and think about processes behind flooding, be it site-specific peculiarities or fundamental hydroclimatological processes.

Hydrology or water resources engineering classes in which flood frequency analysis is taught traditionally delve into the details of performing a statistical frequency analysis and generally minimize the physical, hydroclimatology that underlie the predictability of flood events. The emphasis on the statistics of flood frequency analysis leaves students with little information on causative processes while other portions of the curriculum may tend to present methods that oversimplify fundamental relationships between precipitation and stream discharge. For instance, in engineering courses students are often taught how to estimate design storm runoff magnitudes using methods such as the Soil Conservation Service Curve Number approach that implicitly (and somewhat improperly) equates the runoff or flood frequency with the rainfall frequency (SCS, 1972). This is coupled with popular media accounts of changes in flooding due to a changing climate that presumes increases in rainfall intensity will always result in increases in flooding, despite research showing that this is not necessarily a valid assumption (e.g. Lins and Slack, 1999; Douglas et al., 2000; Shaw and Riha, 2011). In the standard approach to teaching flood frequency analysis, students are left with little background to address the portion of the problem most relevant to contemporary hydrology: how will flood risk change in a changing climate?
This gap in teaching comes at a time when there are new insights in the atmospheric science and hydrometeorology literature that can provide a basis on which to make judgments on how to formulate statistical models of flood frequency that account for non-stationarity. For instance, recent synthesis and modeling research has provided new information on various hydroclimatological phenomenon with direct linkages to flooding, from the genesis of hurricanes in the Atlantic Ocean (Villarini et al., 2011a) to atmospheric rivers (Dettinger, 2011) to snowmelt at high elevations (Rasmussen et al., 2011). Of particular note, many of these hydroclimatological drivers have a distinct regional signature. In returning to the idea of comparative analysis, a comparative hydrologic analysis across geographic regions naturally forms a framework within which to discuss these differences in hydroclimatological drivers and to think about how statistical model structure may need to change in different ways in different places.

Thus, the remainder of this paper will offer an example of how comparative analysis could be used to supplement traditional instruction on the statistical aspects of flood frequency analysis. Due to the varying interpretation of the meaning of comparative analysis, in this paper, comparative analysis is meant to indicate a side-by-side compariosn of processes in different geographic regions. The specific objectives of this paper are to (1) present a visual comparison of the differing nature of daily average and peak flows across regions and offer the comparison as a potential teaching exercise for accompanying statistical analysis of flooding, particularly when discussing issues of non-stationarity; (2) consider how comparative analysis of discharges motivates the investigation of hydroclimatological concepts and leads to insights into the varying levels of confidence in flood predictions made in different locales, and (3) identify other hydrologic concepts that would benefit from a teaching approach based on comparative analysis.

\section{Identifying causative flood processes: illustrating comparative analysis}

\subsection{Methodology}

Data comparisons are constructed using discharge records at USGS flow gages (Table 1). Gage locations were selected to represent distinct discharge characteristics representative of relatively wide geographic areas. All gages had at least $30 \mathrm{yr}$ of record with most having more than $60 \mathrm{yr}$ of record. Most gaged watersheds were on the order of $10000 \mathrm{~km}^{2}$ (with the intended exception of one very small basin), and thus they reflect relatively large-scale hydroclimatological phenomenon. Streamflow records had minimal influence from diversions or impoundment with the exception of the Smoky Hill River gage which was intentionally selected to be below a dam. Two pieces of discharge data are presented in the analysis: 
Table 1. Summary information of watersheds used in comparative analysis.

\begin{tabular}{lllrl}
\hline Figure & River & Gage Location \& USGS ID & Size $\left(\mathrm{km}^{2}\right)$ & Period of Analysis \\
\hline 2a & Yampa River & Maybell, CO (9251000) & 8730 & $1916-2010$ \\
2b & Yadkin River & Yadkin College, NC (2116500) & 5837 & $1929-2010$ \\
2c & St. John River & Dickey, ME (01010500) & 6861 & $1947-2010$ \\
2d & Umpqua River & Winchester, OR (14319500) & 3441 & $1909-2010$ \\
2e & Delaware River & Trenton, NJ (1463500) & 17357 & $1913-2010$ \\
2f & Cedar River & Conesville, IA (5465000) & 19935 & $1940-2010$ \\
3b & Smoky Hill River & Langley, KS (6865500) & 20114 & $1941-2010$ \\
3a & Marsh Creek & Glenmore, PA (1480675) & 22 & $1967-2010$ \\
\hline
\end{tabular}

mean daily flow and annual instantaneous peak flow. Raw discharge data as reported by USGS was adjusted to ease visual comparison: (1) volumetric discharge (i.e. $\mathrm{ft}^{3} \mathrm{~s}^{-1}$ ) was divided by watershed area (and converted to metric) so discharge is instead reported in $\mathrm{mm} \mathrm{day}^{-1}$, (2) mean daily flows were scaled upwards by a factor of 10 so that their magnitudes were closer to those of peak flows, and (3) discharges were presented against Julian Day. In presenting discharge versus Julian day, we emphasize the importance of comparing variations in timing of discharges across the year instead of looking at interannual variability. With the annual peak discharge data, we also undertook a traditional flood frequency analysis and fit the annual peaks of each river system to a GEV distribution using L moments (Stedinger, 1993).

\subsection{A teaching exercise using visual comparisons}

Graphics of the daily mean discharge and annual maximums are shown in Fig. 2. It is quite apparent that each gage site has a relatively unique signature. Differences in signature originate from several features. First, the aridity of the site (average annual potential evapotranspiration versus average annual precipitation as shown in Fig. 1) largely determines the magnitude of the discharges. For instance, the Yampa River in Colorado (Fig. 2a) clearly has the lowest peak discharges and the lowest annual discharge (when considered by looking at the integral of the average daily discharge curve), as might be expected for a site with a potential evapotranspiration to precipitation (PET/P) ratio over one as shown on Fig. 1.

Second, there are differences in seasonality of annual average flows. Some rivers have relatively brief periods of high flow driven by snowmelt signals (the St. John River and Yampa River). Some have more uniform flow over most of the year (the Yadkin River). Some rivers have their highest flows in spring and summer (Cedar River) while others have their highest flows in fall and winter (Umpqua River). Others rivers show signatures of all the above: a snowmelt signal, higher flows in spring and winter, lower flows in summer and fall, but relatively moderate flow over all periods of the year (Delaware River).

Third, watersheds have differences in timing of annual peaks. In many cases, peaks align in timing with daily mean

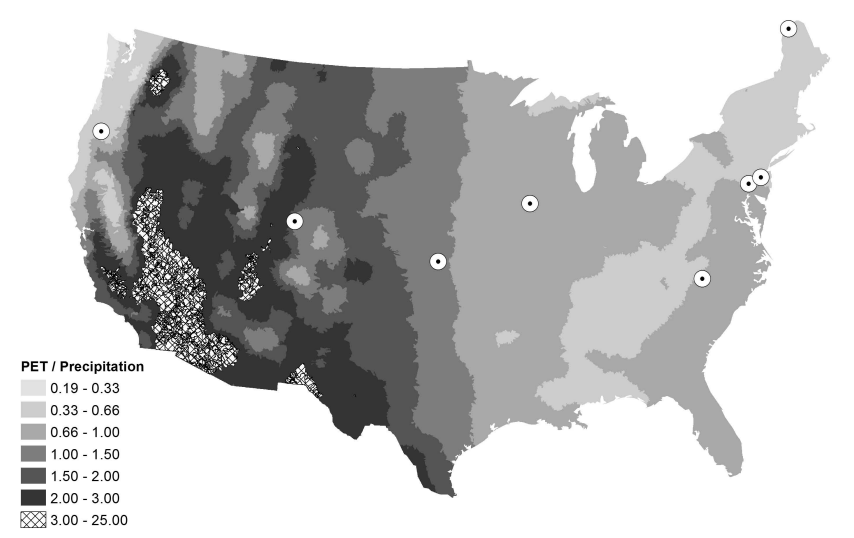

Fig. 1. Location of gages used in comparative analysis. The gages have been overlayed on a map of the aridity index (the ratio of annual potential evapotranspiration to annual precipitation). To replicate a teaching exercise for students, river gages have intentionally not been identified; it would be the task of the students to match the discharge data in Figs. 2 and 3 with the location markers in Fig. 1.

flows (Yampa, St. John, Cedar, Umpqua) but in others the peaks are spread throughout the year with some discordance from daily mean flows (Yadkin and Delaware). As a teaching exercise, one can easily imagine having students match discharge data (Fig. 2a to f) to geographic location (Fig. 1) by letting them make use of their intuitive sense of differences in hydroclimatological drivers. Additionally, there are publications such as the USGS Water Supply Paper 2375 (USGS, 1991) that provide a brief overview of differing hydroclimatic processes in different states in the US. A quick skimming of such a document would provide background information that could help students match discharge signature to location. This exercise was tested on a group of National Weather Service flood forecasters from different regions of the US. While most matches were made relatively easily, it was interesting to note that this different way of organizing discharge provided some challenge, even to the professional flood forecasters. For instance, there was uncertainty over the proper assignment of the Cedar and Delaware Rivers, with the Delaware River signature being mistaken for the 

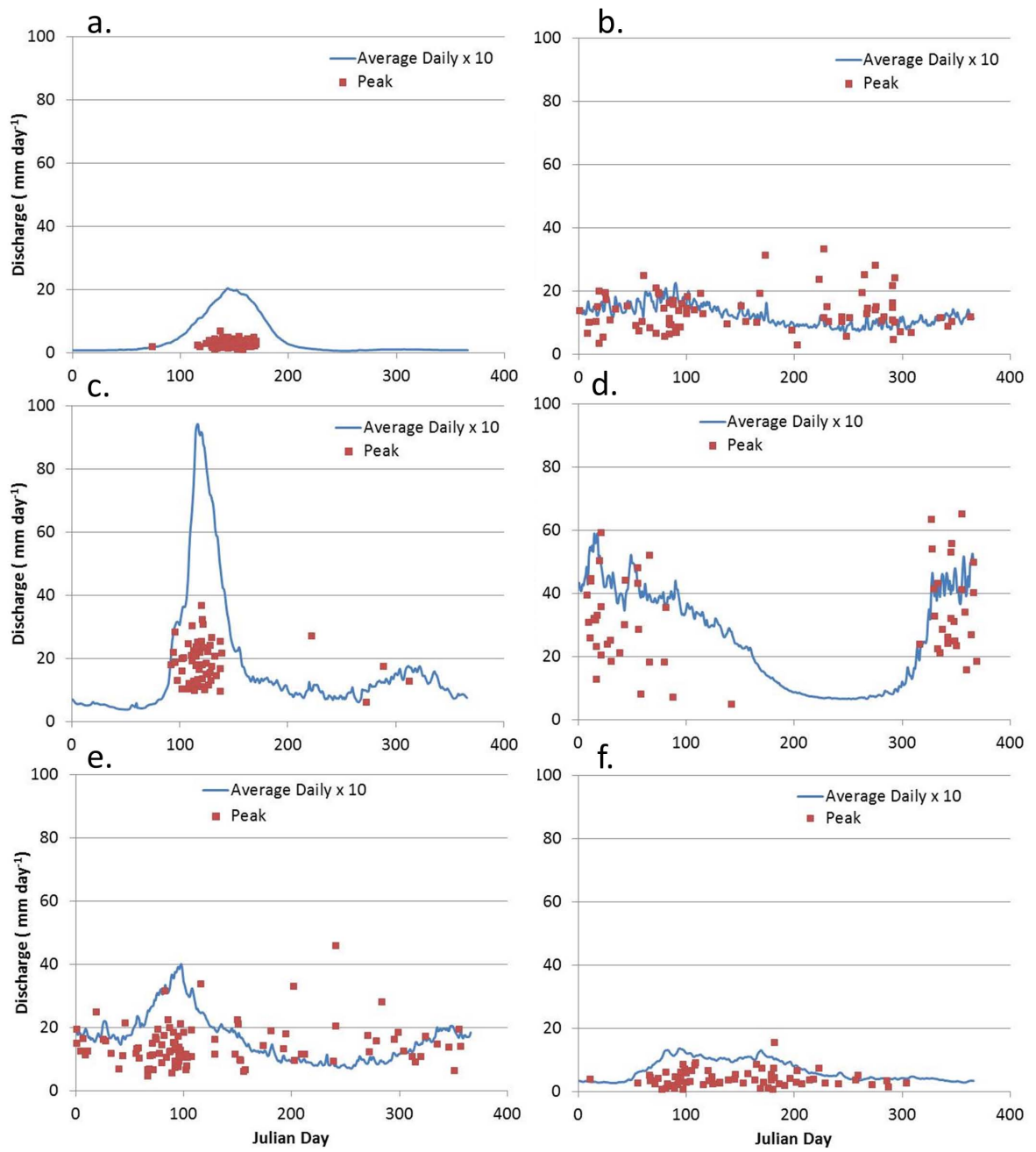

Fig. 2. Average daily discharge and peak annual discharge plotted against Julian Day for watersheds in varying hydroclimatological regions across the US (a) Yampa River, CO; (b) Yadkin River, NC; (c) St. John River, ME; (d) Umpqua River, OR.; (e) Delaware River, NJ; and the (f) Cedar River, IA. Note, as a point of reference, Julian day 122 corresponds to 1 May and Julian day 275 corresponds to 1 October.

Cedar River signature (Comet Advanced Hydrologic Science Course, 18 August 2011). Given the rather distinct signature of the Cedar and Delaware Rivers, it would suggest that there is a certain amount of information provided by such comparative figures that hydrologists (whether students or professionals) are not accustomed to looking at. Notably, in looking at the parameters of a GEV distribution fit to each data set (Table 2), there is information on the magnitude of the resulting discharges (in the scale parameter), and there is information on the possibility of low-probability, high-magnitude thick-tail events (in the skew parameter) but there is little other insight offered into the underlying processes. These summary statistics of the probability distribution are all that students are traditionally left to consider in terms of describing the future prospects for flooding at a given site.

\subsection{A teaching exercise on causative processes and their sensitivity to climate change}

This comparative analysis provides a logical entrance for students to identify and learn about differing flood-causative processes and their predictability in a changing climate. The underlying causative processes in our selected river basins of study can be divided into five primary categories: snowmelt (the Yampa and St. John River), hurricanes (the Yadkin River), atmospheric rivers (the Umpqua River), multi-day sustained rainfall (the Cedar River), and mixed causative processes (the Delaware River).

Certain causative processes - such as snowmelt, hurricanes, and mixed processes - are relatively apparent from examination of the discharge plots alone. For instance, snowmelt-dominated systems have virtually all flood peaks occurring in late spring and early summer. 
Table 2. Parameters of GEV distribution fit to six river's annual maximum discharges. This typical outcome of a flood frequency analysis offers little information to help improve student intuition of dominant flood processes.

\begin{tabular}{lrrr}
\hline River & $\begin{array}{r}\text { Alpha } \\
\text { (scale) }\end{array}$ & $\begin{array}{r}\text { Epsilon } \\
\text { (location) }\end{array}$ & $\begin{array}{r}\text { Kappa } \\
\text { (skew) }\end{array}$ \\
\hline Yampa River & 0.86 & 2.49 & 0.14 \\
Yadkin River & 4.79 & 10.60 & -0.0024 \\
St. John River & 5.92 & 16.27 & 0.17 \\
Umpqua River & 13.15 & 26.43 & -0.00026 \\
Delaware River & 4.46 & 11.47 & -0.080 \\
Cedar River & 1.79 & 2.87 & -0.085 \\
\hline
\end{tabular}

Hurricane-dominated systems have the very largest peaks occurring in late summer and early fall. Systems with mixed causative processes have some spring melt peaks but also occasional peaks in late summer and fall (plus the addition of numerous peaks with less apparent origins).

Other causative flood processes are most apparent when additional supplementary knowledge of the systems in provided. Atmospheric rivers - long, narrow bands of high atmospheric moisture content most typically identified over the Pacific Coast off the western US - are readily visible with remote microwave sensing. With the advent of microwave sensing in the last two decades, nearly all large precipitation events in the coastal west have been linked to atmospheric rivers (Dettinger, 2011). In the Midwest, the importance of sustained rainfall as a cause of flood peaks is evident from analyses of recent major flooding, such as in 2008. A case study of flooding in the upper Midwest demonstrated that many floods were the outcome of more than 10 consecutive days of moderate rainfall (Budikova et al., 2010). This sensitivity to multi-day events is most likely furthered by the relatively flat slopes and deep soils of the region (Chen and Kumar, 2001) that act to attenuate precipitation inputs.

Given the difference in underlying processes, students could then be asked to propose the type of modifications that would make existing statistical models suitable under non-stationary conditions (e.g. make the mean or location parameter time dependent, change weighting of mixed model, etc.). In Table 3 we present some possible ways to modify statistical models of flood frequency to account for nonstationarities. As an exercise, students could construct a table similar to Table 3 .

Justifying such changes to the statistical models is dependent on having some knowledge of projected future changes in the different hydroclimatological processes behind flooding in different locales. With such processes identified, students would find some clear distinctions in the predictability of future changes in the flooding processes.

For instance, it is rather well established that lowelevation, snow-melt dominated systems will see a decline in snow pack and presumably a decline in spring flood flows (Adam et al., 2009) as the rain-snow line moves upwards in elevation. These low-elevation systems are relatively predictable given that they have a well-understood process driver and validation in modeling efforts. Therefore, in constructing a framework similar to Table 3, a student may note that modifications to the statistical model for the St. John's River could be made with relatively high confidence. Predicted future changes in high-elevation, snowdominated systems remain less consistent across models, but recent work has identified the sensitivity of modeling to the choice of spatial resolution and the representation of topographical features (Rasmussen et al., 2011). Presuming these factors of resolution and topography can be properly parameterized, it would seem that changes in snowpack size (and thus potential spring snowmelt) could be relatively predictable. Work such as that by Rasmussen et al. (2011) in higher elevations predict reductions in total snowfall offset by increases in total snowfall, leading to a negligible net change in total snowpack mass and potential flood maximum. Consequently, in constructing Table 3, a student may find that modifications to the statistical model for the Yampa River in Colorado could be made with moderate confidence.

At the other end of the spectrum are hurricanes. There remain varying arguments for why hurricane intensity (let alone the proclivity for hurricanes to make land fall and generate large precipitation amounts) may or may not change in a changing climate. However, there is new research indicating that predictability by way of modeling with downscaled general circulation models may inherently be challenging. Namely, Villarini et al. (2011a) have observed that when different models simulate hurricanes, the model predictions depend on the relative difference between mean Atlantic Ocean temperature and tropical Atlantic temperature (not just the mean temperature) and that there remains little likelihood of understanding these small but important variations in model sea surface temperatures. Along these same lines, Kossin et al. (2010) categorized hurricane type by region of genesis and found that hurricanes forming in the most southern latitudes tended to be the most intense and long-lived (and presumably wettest). Hurricane genesis in these southerly Atlantic regions is dependent on position of the Africa easterly jet, a mesoscale feature that Kossin et al. (2010) noted may be challenging for most models to reproduce. In constructing Table 3, a student may decide that while the type of modification to be made to the standard statistical made is relatively clear (allowing a trend in the mean or location parameter of the distribution) the direction of this shift remains highly uncertain.

In rivers subject to mixed causative processes (i.e. hurricanes, snowmelt, and convective events) it would seem that higher frequency events associated with snowmelt could be predicted but that very low-frequency events associated with hurricanes may remain uncertain, raising the counterintuitive possibility that low magnitude flood events could be predicted but high magnitude events may not be. In Table 3, 
Table 3. Illustration of a teaching exercise that draws connections between a river, dominant flood processes, changes in statistical models due to non-stationary climate drivers, and the confidence in the suitability of the change to the statistical model.

\begin{tabular}{llll}
\hline River & $\begin{array}{l}\text { Dominant flood } \\
\text { processes }\end{array}$ & $\begin{array}{l}\text { Statistical model } \\
\text { change }\end{array}$ & $\begin{array}{l}\text { Confidence in statistical } \\
\text { model changes }\end{array}$ \\
\hline Yampa River & $\begin{array}{l}\text { Snowmelt from high } \\
\text { elevations }\end{array}$ & $\begin{array}{l}\text { Downward trend } \\
\text { in mean }\end{array}$ & Moderate Confidence \\
\hline Yadkin River & Atlantic Hurricanes & Upward trend in mean & Low Confidence \\
\hline St. John River & $\begin{array}{l}\text { Snowmelt from medium } \\
\text { elevations }\end{array}$ & Downward trend in mean & High confidence \\
\hline Umpqua River & $\begin{array}{l}\text { Atmospheric Rivers from } \\
\text { Pacific Ocean }\end{array}$ & Upward trend in mean & Moderate Confidence \\
\hline Delaware River & $\begin{array}{l}\text { Atlantic Hurricanes, } \\
\text { Snowmelt, Convective } \\
\text { Events, Others }\end{array}$ & $\begin{array}{l}\text { Change in weighting in } \\
\text { mixture model }\end{array}$ & Moderate to Low Confidence \\
\hline Cedar River & $\begin{array}{l}\text { Multi-day Precipitation } \\
\text { Events }\end{array}$ & Upward trend in mean & Low Confidence \\
\hline
\end{tabular}

a student might qualify the varying levels of confidence depending on the return period of the event trying to be predicted.

Other flood-causing processes fall somewhere in the middle in terms of potential predictability. The bands of high vapor flux indicative of atmospheric rivers are actually reproduced by general circulation models (GCM) (Dettinger, 2011), in contrast to phenomena such as hurricanes which to date must be simulated with a dynamic downscaling model. While there are inconsistencies among GCMs in the degree of change in atmospheric river frequency and intensity, the simple fact the climatological feature is reproduced suggest that there is good reason to believe these phenomenon may be predicted with some certainty although, notably, different GCMs currently give differing future predictions (Dettinger, 2011). In Table 3, we note that flooding caused by atmospheric rivers in the Umpqua River could be presumed to be increasing (thus an upward trend in the mean) with moderate confidence. Sustained rainfall in the Midwest is also only recently being understood from the perspective of the source of the moisture. But, in so doing, there are suggestions that the most intense delivery of moisture occurs from processes similar to atmospheric rivers from the $\mathrm{Pa}$ cific. In this case it is due to moisture originating from the Gulf of Mexico (Dirmeyer and Kinter, 2010). However, such processes remain very open to additional fundamental scientific research. With this information, in constructing Table 3, a student might decide that modifications to the statistical model for the Cedar River can only be made with low confidence.

In compiling the information such as that found in Table 3, students would find that while in some regions there are statistical models that can be supported by relatively convincing arguments for future changes in climatological phenomenon (i.e. snowmelt in low elevation mountain ranges), other regions continue to have ambiguities in how major floodcausative processes will change (i.e. hurricanes). Instead of leaving students with the impression that increases in flood frequency in a changing climate are a universal expectation known with certainty, this comparative analysis of the state of the science explaining causative processes helps students develop a more nuanced understanding of regional variation in the predictability of changes in flooding.

\subsection{Where does this exercise fit in a semester long class?}

This exercise would be a small part of any semester long class. Certainly, it could be presented within a traditional physical hydrology class that introduces standard, reductionist-based techniques of hydrologic analysis (unit hydrographs, Green-Ampt infiltration, kinematic wave, etc.). However, this exercise could also be part of a curriculum that builds more intangible skills such as data interpretation, synthesis, and model conceptualization. Such skills are essential to deal effectively with issues of non-stationarity, system complexity, and uncertainty that will very likely be at the core of the most pressing problems in hydrology in the coming decades (Ngamebki et al., 2012).

A description of how this exercise is incorporated into the authors' classes provides some context into how it can be used in a curriculm intended to teach these intangible skills. Both authors of this paper currently teach classes that explicitly consider changes in hydrology in a changing climate. Shaw's class uses this exercise as one of several that attempt to bridge the gap between teaching traditional tools of hydrologic analysis and enhancing critical thinking and flexible data analysis. In one exercise, students analyze surface air 

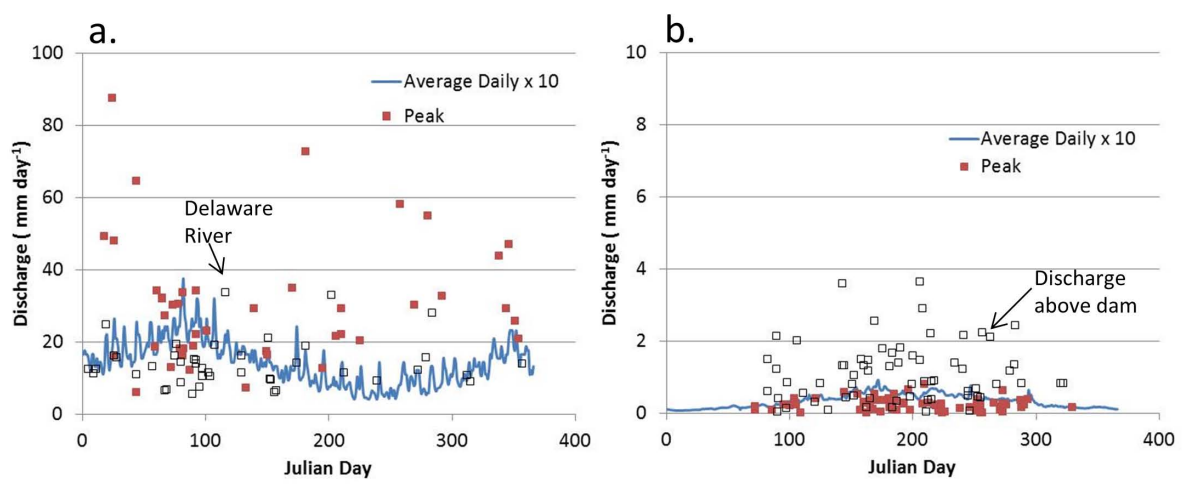

Fig. 3. Average daily discharge and peak annual discharge plotted against Julian Day for Marsh Creek, PA (panel a) and the Smoky Hill River, KS (panel b). In (a), the open symbols show annual peak from the Delaware River at Trenton from 1967-2010. In (b), the open symbols indicate annual peaks from an upstream gage on the Smoky Hill River not influenced by a dam.

maps from the National Weather Service to (1) calculate recycling ratios (following Trenberth, 1998) for different storm events in different regions and (2) to roughly track the origin of moisture heading into a region (following Gimeno et al., 2010 and Van der Ent et al., 2010). In another exercise, Shaw has students (1) evaluate the relationship between precipitation and temperature in accordance with the ClausiusClaperyon relationship (Lenderink and van Meijgaard, 2008 and Shaw et al., 2011) for different duration rainfall events in different locations and concurrently (2) evaluate variability of runoff ratios across storm events in different regions to assess dependencies on antecedent conditions.

Walter's class is organized around the idea of evaluating how different investigations of hydrologic changes in a changing climate make use of different climate observation data and climate model output. From readings drawn from the academic literature, students work to assess how climate information is translated to regional and watershed level hydrologic behaviors. The students apply a level of comparative analysis to tease out differences in linkage between climate predictions and observations and the predicted terrestrial hydrology among different regions. This exercise on flooding is used to motivate open-ended discussions of differing hydroclimatological processes and how they are resolved in climate models.

\section{Conclusions}

This paper examines the value of comparative hydrology in deciphering different flood causative processes in different regions. By looking at the timing of annual peak flows (i.e. by plotting against Julian day) across regions instead of just looking at the time series or probability distribution of peaks, students can visually identify fundamental differences in the causative mechanisms of floods in different regions. Students can then be asked to investigate the degree to which different causative mechanisms can be predicted in a changing climate. In merging this type of comparative analysis exercise with standard flood frequency analysis, students benefit from a better sense of the variation in underlying flood-causative processes and gain better intuition on how and when to implement changes to statistical models in a non-stationary world. In the context of other recent thinking on education in the hydrologic sciences, such an exercise helps build the horizontal bar of the so-called T-shaped competency profile (Uhlenbrook and de Jong, 2012) by expanding knowledge of disciplines adjacent to a hydrologist's core area of expertise.

Although we have focused on the relationships between hydroclimatology and flooding, comparative hydrology could also be used to help students develop important process-based insights for a variety of factors influencing hydrology. One important factor that would readily fall out of a comparative analysis is the issue of scale. For instance, in Fig. 3a we show the annual maximum discharges and mean annual discharges versus Julian day for a $20 \mathrm{~km}^{2}$ watershed (Marsh Creek) and also overlay the annual peaks from 1967-2010 (the period of overlap between the two records) for the nearby $17537 \mathrm{~km}^{2}$ Delaware River (also shown individually in Fig. 2e). As presented, the comparative analysis delves into the question of how catchment size influences flood peak per unit area. From Fig. 3a, it is apparent that per unit area, the majority of annual peaks in Marsh Creek are larger than annual peaks on the larger Delaware River. Additionally, while the largest peak on the Delaware River is approximately $35 \mathrm{~mm} \mathrm{day}^{-1}$, the largest peaks on Marsh Creek exceed $80 \mathrm{~mm} \mathrm{day}^{-1}$, with most of these occurring in either early winter or late summer. This suggests that certain processes (such as rapid snowmelt for the winter discharge events and convective rainfall for the summer events) may have a strong scale dependence. There are certainly numerous other scale related issues to highlight with comparative analysis. Additional ones include questions such as: do smaller watersheds always have lower baseflows per unit area 
(e.g. Frisbee et al., 2011) or does the same percentage of land use change affect big and small watersheds the same way?

Another important factor affecting hydrology amenable to comparative analysis is the influence of land use and other watershed features on discharge. In Fig. 3b, we present annual peaks for the Smoky Hill River, above and below a dam. Notably, the construction of a dam is often offered as clear cause of a change point in long-term record of flow (Villarini et al., 2011b). Interestingly, at least for this site, while it appears that the dam certainly reduces the magnitude of discharge, it does not necessarily change the range of the time of year over which a peak flow can occur given that both data sets have peaks between Julian days of 80 and 330. Additional analyses could specifically highlight for students the impact of different land covers (in terms of both percentage and spatial distribution) or the scale at which upstream impoundments do not have a measurable impact on discharge.

Comparative hydrology could also be worthwhile to help synthesize and organize the myriad of empirical relationships that often unavoidably show up in hydrology. For instance, in teaching methods of evapotranspiration, most textbooks will ultimately provide at minimum five different methods to estimate potential evapotranspiration (e.g. scaling of pan evaporation, Penman, Penman-Monteith, Priestly-Taylor, Hargreaves, Thornthwaite, Bowen Ratio). While brief caveats are often given about the appropriateness of different formulations, there is often little illustration of how varied the estimates can be across the different methods, especially when considered in terms of the sensitivity to different climate drivers. Since many students do not go on to become research hydrologists, more definitive, comparative information on the adequacy and limitations of different methods would help avoid their misuse, especially in cases where simpler, more empirical formulations are calibrated to existing hydroclimatological conditions. Such methodological comparisons could certainly be applicable to other applied hydrology topics such as snowmelt functions or infiltration functions.

In this paper, we have offered several suggestions for using comparative analysis to help teach fundamental lessons in hydrology. Comparative analysis potentially has great value in hydrologic sciences education. It is well suited to teaching topics of current relevance (climate change, land use change) while at the same time helping linking traditional physics and math based hydrologic theory with skills in synthesizing across place and discipline. We hope this paper serves as an impetus for comparative analysis to become a more standard tool in both the teaching and research of hydrology.

Acknowledgements. We thank Katherine Hirschboeck and Murugesu Sivapalan for their thoughtful and constructive reviews.

Edited by: T. Wagener

\section{References}

Adam, J. C., Hamlet, A. F., and Lettenmaier, D. P.: Implications of global climate change for snowmelt hydrology in the twenty-first century, Hydrol. Process., 23, 962-972, 2009.

Andrade, E. M.: Regionalization of small watersheds in arid and semiarid regions: cluster and Andrews' curve approaches, Eng. Agric., 18, 39-52, 1999.

Andreassian, V.: Waters and forests: from historical controversy to scientific debate, J. Hydrol., 291, 1-27, 2004.

Black, P. E.: Watershed Hydrology. Prentice Hall, Englewood Cliffs, New Jersey, 408 pp., 1991.

Blöschl, G. and Sivapalan, M.: Process controls on regional flood frequency: Coefficient of variation and basin scale, Water Resour. Res., 33, 2967-2980, 1997.

Brutsaert, W.: Hydrology: An Introduction, Cambridge University Press, Cambridge, 605 pp., 2005.

Budikova, D., Coleman, J. S. M, Strope, S. A., and Austin, A.: Hydroclimatology of the 2008 Midwest floods, Water Resour. Res., 46, W12524, doi:10.1029/2010WR009206, 2010.

Chen, J. and Kumar, P.: Topographic influence on the seasonal and interannual variation of water and energy balances in North America, J. Climate, 14, 1989-2014, 2001.

de Araujo, J. C. and Gonzalez Piedra, J. I.: Comparative hydrology: analysis of a semiarid and a humid tropical watershed, Hydrol. Process., 23, 1169-1178, 2009.

Dettinger, M.: Climate change, atmospheric rivers, and floods in California - A multimodel analysis of storm frequency and magnitude changes, J. Am. Water Resour. As., 47, 514-523, 2011.

Dirmeyer, P. A. and Kinter, J. L.: Floods over the Midwest: A Regional Water Cycle Perspective, J. Hydrometeorol., 11, 11721181, 2010.

Dingman, S. L.: Physical Hydrology, Waveland Press, Illinois, 2002.

Douglas, E. M., Vogel, R. M., and Kroll, C. N.: Trends in floods and low flows in the United States: impact of spatial correlation, J. Hydrol., 240, 90-105, 2000.

Dunne, T. and Leopold, L. P.: Water in Environmental Planning, W. H. Freeman \& Co., New York, 818 pp., 1978.

Eagleson, P.: Dynamics of Flood Frequency, Water Resour. Res., 8 , 878-898, 1972.

El Adlouni, S., Ouarda, T., Zhang, X., Roy, R., and Bobée, B.: Generalized maximum likelihood estimators for the nonstationary generalized extreme value model, Water Resour. Res., 43, doi:10.1029/2005WR004545, W03410, 2007.

Fiorentino, M. and Iacobellis, V.: New insights about the climatic and geologic control on the probability distribution of floods, Water Resour. Res., 37, 721-730, 2001.

Frisbee, M. D., Phillips, F. M., Campbell, A. R., Liu, F., and Sanchez, S. A.: Streamflow generation in a large, alpine watershed in the Southern Rocky Mountains of Colorado: Is streamflow generation simply the aggregation of hillslope runoff responses, Water Resour. Res., 47, W06512, doi:10.1029/2010WR009391, 2011.

Gassman, P. W., Reyes, M. R., Green, C. H., and Arnold, J. G.: The Soil and Water Assessment Tool: Historical Development, Applications, and Future Research Directions, T. ASABE, 50, 1211-1250, 2007.

Gimeno, L., Drummond, A., Nieto, R., Trigo, R. M., and Stohl, A.: On the origin of continental precipitation, Geophys. Res. Lett., 
37, L113804, doi:10.1029/2010GL043712, 2010.

Hirschboeck, K. K.: Flood Hydroclimatology, in: Flood Geomorphology, edited by: Baker, V. R., Kochel, R. C., and Patton, P. C., John Wiley \& Sons, 27-49, 1988.

Hirschboeck, K. K., Ely, L., and Maddox, R. A.: Hydroclimatology of meteorologic floods, in: Inland Flood Hazards: Human, Riparian, and Aquatic Communities, edited by: Wohl, E., Cambridge University Press: Cambridge, 39-72, 2000.

Hornberger, G. M.: Elements of Physical Hydrology, John Hopkins University Press, Baltimore, Maryland, 307 pp., 1998.

Horton, R. E.: The role of infiltration in the hydrologic cycle, EOS T. Am. Geophys. Un., 14, 446-460, 1933.

Katz, R. W., Parlange, M. B., and Naveau, P.: Statistics of extremes in hydrology, Adv. Water Resour., 25, 1287-1304, 2002.

Kossin, J. P., Camargo, S. J., and Sitkowski, M.: Climate modulation of North Atlantic Hurricane Tracks, J. Climate, 23, 3057-3076, 2010.

Leclerc, M. and Ouarda, T. B. M. J.: Non-stationary regional flood frequency analysis at ungauged sites, J. Hydrol., 343, 254-265, 2007.

Lenderink, G. and van Meijgaard, E.: Increase in hourly precipitation extremes beyond expectations from temperature changes, Nat. Geosci., 1, 511-514, 2008.

Lins, H. F. and Slack, J. R.: Streamflow trends in the United States, Geophys. Res. Lett., 26, 227-230, 1999.

Mayer, B., Boyer, E. W., Goodale, C., Jaworski, N. A., Van Breeman, N., Howarth, R. W., Seitzinger, S., Billen, G., Lajtha, L. J., Nosal, M., and Paustian, K.: Sources of nitrate in rivers draining sixteen watersheds in the northeastern US: Isotopic constraints, Biogeochemistry, 57, 171-197, 2002.

Merz, R. and Blöschl, G.: Flood frequency hydrology: 1. Temporal, spatial, and causal expansion of information, Water Resour. Res., 44, W08432, doi:10.1029/2007WR006744, 2008.

Merz, R. and Blöschl, G.: A regional analysis of event runoff coefficients with respect to climate and catchment characteristics, Water Resour. Res., 45, W01405, doi:10.1029/2008WR007163, 2009.

Milly, P. C. D., Betancourt, J., Falkenmark, M., Hirsch, R. M., Kundzewicz, Z. W., Lettenmaier, D. P., and Stouffer, R. J.: Stationarity Is Dead: Whither Water Management, Science, 319, 573-574, 2008.

Ngambeki, I., Thompson, S. E., Troch, P. A., Sivapalan, M., and Evangelou, D.: Engaging the students of today and preparing the catchment hydrologists of tomorrow: student-centered approaches in hydrology education, Hydrol. Earth Syst. Sci. Discuss., 9, 707-740, doi:10.5194/hessd-9-707-2012, 2012.

Peters, N. E., Shanley, J. B., Aulenbach, B. T., Webb, R. M., Campbell, D. H., Hunt, R., Larsen, M. C., Stallard, R. F., Troester, J., and Walker, J. F.: Water and solute mass balance of five small, relatively undisturbed watersheds in the US, Sci. Total Environ., 358, 221-242, 2006.

Porto, M. M., Andrade, E. M., de Costa, R. N. T., de A. Lemos Filho, L. C., and Meireles, M.:Identification of homogeneous groups of watersheds in Ceara state, Brazil, Rev. Cienc. Agron., 35, 17-25, 2004.

Rasmussen, R., Liu, C., Ikeda, K., Gochis, D., Yates, D., Chen, F., Tewari, M., Barlage, M., Dudhia, J., Yu, W., and Miller, K.: High-resolution coupled climate runoff simulations of seasonal snowfall over Colorado. A process study of current and warmer climate, J. Climate, 24, 3015-3048, 2011.

Robinson, J. S. and Sivapalan, M.: An investigation info the physical causes of scaling and heterogeneity of regional flood frequency, Water Resour. Res., 33, 1045-1059, 1997.

Rossi, R., Fiorentino, M., and Versace, P.: Two-component extreme value distribution for flood frequency analysis, Water Resour. Res., 20, 847-856, 1984.

Shaw, S. B. and Riha, S. J.: Assessing Possible Changes in Flood Frequency Due to Climate Change in Mid-sized Watersheds in New York State, USA, Hydrol. Process., 25, 2542-2550, 2011.

Shaw, S. B., Royem, A. A., and Riha, S. J.: The relationship between extreme hourly precipitation and surface temperature in different hydroclimatic regions of the US, J. Hydrometeorol., 12, 319-325, 2011.

Sivapalan, M. and Samuel, J. M.: Transcending limitations of stationarity and the return period: process-based approach to flood estimation and risk assessment, Hydrol. Process., 23, 16711675, 2009.

Sivapalan, M., Yaeger, M. A., Harman, C. J., Xu, X., and Troch, P. A.: Functional model of water balance variability at the catchment scale. 1: Evidence of hydrologic similarity and space-time symmetry, Water Resour. Res., 47, W02522, doi:10.1029/2010WR009568, 2011.

Stedinger, J. R.: Frequency Analysis of Extreme Events, in: Handbook of Hydrology, edited by: Maidment, D. R., McGraw-Hill, New York, 18.1-18.66, 1993.

Stedinger, J. R. and Griffis, V. W.: Getting from here to where; Flood frequency analysis and climate, J. Am. Water Resour. As., 47, 506-513, 2011.

Thompson, S. E, Harman, C. J., Konings, A. G., Sivapalan, M., Neal, A., and Troch, P. A.: Comparative hydrology across AmeriFlux Sites. The variable roles of climate, vegetation, and groundwater, Water Resour. Res., 47, W00J07, doi:10.1029/2010WR009797, 2011.

Trenberth, K. E.: Atmospheric moisture recycling: Role of Advection and local advection, J. Climate, 12, 1368-1381, 1998.

Tripler, C., Kaushal, S. S., Likens, G. E., and Walter, M. T.: Environmental change and the role of potassium in forested ecosystems, Ecol. Lett., 9, 451-466, 2006.

Uhlenbrook, S. and de Jong, E.: T-shaped competency profile for water professionals of the future, Hydrol. Earth Syst. Sci. Discuss., 9, 2935-2957, doi:10.5194/hessd-9-2935-2012, 2012.

US Geological Survey (USGS): National Water Summary 19881989, Hydrologic Events and Floods and Droughts, Water Supply Paper 2375, United State Geological Survey, Government Printing Office, Washington DC, 591 pp., 1991.

US Soil Conservation Service (SCS): Hydrology, in: National Engineering Handbook, US Gov. Print. Off., Washington DC, available at: http://www.nrcs.usda.gov/wps/portal/ nrcs/detailfull/national/wntsc/?\&cid=stelprdb1043063 (last access: 24 March 2012), 1972.

van der Ent, R. J., Savenije, H. H. G., Schaefli, B., and SteeleDunne, S. C.: Origin and Fate of Moisture over Continents, Water Resour. Res., 46, W09525, doi:10.1029/2010WR009127, 2010.

Viessman, W. and Lewis, G. L.: Introduction to Hydrology, Pearson Education, NY, 612 pp., 2003.

Villarini, G. and Smith, J. A.: Flood peak distribution for the eastern U.S., Water Resour. Res., 46, W06504, doi:10.1029/2009WR008395, 2010. 
Villarini, G., Vecchi, G. A., Knutson, T. R., Zhao, M., and Smith, J. A.: North Atlantic Tropical Storm Frequency Response to Anthropogenic Forcing: Projections and Sources of Uncertainty, J. Climate, 24, 3224-3238, 2011a.

Villarini, G., Smith, J. A., Baeck, M. L., and Krajewski, W. F.: Examining Flood Frequency Distributions in the Midwest U.S., J. Am. Water Resour. As., 47, 447-463, 2011 b.

Vitousek, P. M. and Reiners, W. A.: Ecosystem succession and nutrient retention: a hypothesis, BioScience, 25, 376-381, 1975.
Voepel, H., Ruddell, B., Schumer, R., Troch, P. A., Brooks, P. D., Neal, A., Durcik, M., and Sivapalan, M.: Quantifying the role of climate and landscape characteristics on hydrologic partitioning and vegetation response, Water Resour. Res., 47, W00J09, doi:10.1029/2010WR009944, 2011.

Ward, A. D. and Trimble, S. W.: Environmental Hydrology, CRC Press, Boca Raton, Florida, 481 pp., 2004. 